\title{
Determinan Kinerja Anggaran pada Organisasi Perangkat Daerah
}

\author{
Syukriy Abdullah', Afrah Junita ${ }^{2}$ \\ 'Universitas Syiah Kuala, ${ }^{2}$ Universitas Samudra \\ 'syukriyabdullah@unsyiah.ac.id
}

\begin{abstract}
Budget performance is the basis for evaluating and assessing the quality of financial management and budgeting in government organizations, especially in local government's agencies. The purpose of this study is to examine the effect of budget size (TB), budget change (PB), and previous year budget variance (VS) on budget performance (KA) at agencies of Gayo Lues Regency. The sample in this study amounted to 44 work units of regional apparatus (SKPD) for fiscal year 2016-2017. Data analysis using multiple linear regression model. The results show that PB has no effect on KA, while TB and VS have negative effect on KA.
\end{abstract}

Keywords: budget variance, budget changes, prior-year budget balance, budget performance, local government agencies

\begin{abstract}
Abstrak
Kinerja anggaran (KA) merupakan dasar yang digunakan untuk mengevaluasi dan menilai kualitas pengelolaan keuangan dan penganggaran pada organisasi pemerintahan, terutama pada pemerintahan daerah dan unit kerja yang berada di dalamnya. Penelitian ini bertujuan untuk menguji pengaruh Total Belanja (TB), Perubahan Belanja (PB), dan Varian Belanja Tahun Sebelumnya (VS) terhadap Kinerja Anggaran (KA) pada satuan kerja perangkat daerah (SKPD) Kabupaten Gayo Lues. Sampel dalam penelitian ini berjumlah 44 SKPD untuk tahun anggaran 2016-2017. Analisis data menggunakan model regresi linear berganda. Hasil analisis menunjukkan bahwa TB dan VS berpengaruh negatif terhadap KA, sedangkan PB tidak berpengaruh terhadap KA.
\end{abstract}

Kata Kunci: varian anggaran, perilaku oportunistik, peyesuaian anggaran, kinerja anggaran, satuan kerja perangkat daerah 


\section{PENDAHULUAN}

Pengukuran kinerja anggaran organisasi perangkat daerah (OPD) ${ }^{1}$ dalam pengelolaan keuangan daerah sangat penting untuk menilai kemampuan organisasi ini mencapai target yang telah ditentukan dalam Rencana Pembangunan Jangka Menengah Daerah (RPJMD). Tujuan RPJMD sendiri adalah untuk meningkatkan kesejahteraan masyarakat melalui perencanaan dan penggunaan dana publik secara ekonomis, efektif, dan efisien. Oleh karena itu, pengelolaan keuangan di SKPD harus dilaksanakan secara akuntabel, transparan, dan partisipatif, diawali dengan penyusunan anggaran dan diakhiri dengan pertanggungjawaban serta diiringi dengan pengawasan. Semua aspek pengelolaan ini dilaksanakan secara mandiri oleh pemerintah daerah (Pemda) (Abdullah \& Junita, 2016), namun kinerja keuangan SKPD sendiri belum banyak dikaji secara empiris.

Kinerja anggaran seharusnya disampaikan kepada publik dengan prinsip transaransi dan akuntabilitas publik. Transparansi dan akuntabilitas publik dalam pengambilan keputusan anggaran dilaksanakan secara utuh dalam semua tahapan penganggaran, sejalan dengan penerapan prinsip partisipatif, yang membuka ruang untuk terjadinya berbagai persoalan keagenan (agency problems) dalam penyusunan, pembahasan, pelaksanaan, dan pertanggungjawaban anggaran (Fozzard, 2001; Halim \& Abdullah, 2006). Hal ini disebabkan adanya perbedaan kepentingan antara pengusul (OPD/SKPD), tim anggaran Pemda (TAPD), kepala daerah, dan Dewan Perwakilan Rakyat Daerah (DPRD) (Abdullah, 2012; Junita \& Abdullah, 2016). Anggaran yang dikelola secara akuntabel dan transparan dapat meningkatkan kepercayaan publik dan meminimalkan praktik korupsi (Ott, et al., 2018).

Usulan anggaran yang diajukan OPD menjadi bahan untuk penyusunan draf anggaran pendapatan dan belanja daerah (APBD) dan setelah ditetapkan akan menjadi tolok ukur dalam menilai kinerja anggaran OPD bersangkutan. Anggaran juga merupakan alat untuk mengalokasikan sumberdaya dalam rangka memenuhi kebutuhan publik yang dilaksanakan dalam bentuk tindakan berupa layanan oleh OPD, serta untuk memprediksi pendapatan dan pengeluaran di masa depan (Joyce, 2001; Williams \& Calabrese, 2016). Sebagai agent, OPD memiliki kecenderungan untuk memaksimalkan usulan anggaran belanjanya, sehingga terjadi mark-up, yang merupakan slack dalam anggaran.

Ketidakakuratan dalam memprediksi, baik dalam bentuk mark-down pendapatan maupun mark-up belanja, dapat menyebabkan terjadi varian anggaran (budget variances), yakni selisih antara target yang ditetapkan dengan yang terealisasi, yang bermuara pada surplus/defisit ril dan sisa anggaran pada akhir tahun. Varian anggaran ini merupakan salah satu ukuran dalam penilaian kinerja anggaran pemerintahan daerah (Mayper, et al., 1991; Abdullah \& Nazry, 2014), yang terkait erat dengan budgetary slack dalam penganggaran partisipatif (Abdullah, 2008). Kinerja anggaran menjadi fenomena yang dikaji dan didiskusikan oleh politisi, birokrat, dan pembuat kebijakan, terutama pemerintah pusat dalam melakukan pembinaan kepada pemerintah daerah (Rezeki \&

${ }^{1}$ OPD sama dengan satuan kerja perangkat daerah (SKPD) dalam konteks pengelolaan keuangan daerah, yang dalam tulisan ini digunakan bergantian dengan tidak ada perbedaan makna. 
Hasanuddin, 2017; Negara, et al., 2018; Abdullah, et al., 2019). Pada beberapa negara, kinerja anggaran menjadi pertimbangan dalam memilih incumbent untuk menjabat kembali pada periode berikutnya melalui pemilihan umum (Yuliati, et al., 2017; Darmastuti \& Setyaningrum, 2019).

Pengukuran kinerja anggaran merupakan topik diskusi yang sangat penting dalam mengevaluasi dan menilai kualitas pengelolaan keuangan pada organisasi pemerintahan, terutama pada pemerintah daerah dan OPD yang berada di dalamnya. Fenomena politik anggaran di daerah menunjukkan adanya kompetisi dalam pengalokasian sumberdaya di antara OPD, yang kadangkala melibatkan DPRD (Abdullah, 2012). Praktik desentralisasi fungsional dalam penyusunan anggaran melalui partisipasi OPD berimplikasi pada terjadinya senjangan anggaran (Widanaputra \& Mimba, 2014), yang merupakan bentuk bias dalam penganggaran (Lukka, 1988) yang mengandung masalah keagenan (Abdullah \& Halim, 2006). Senjangan anggaran memiliki pengaruh terhadap perubahan anggaran (Forrester, 1993; Forrester \& Mullins, 1992) dan varian anggaran (Abdullah, et al., 2019), sehingga berdampak pada sisa anggaran di akhir tahun yang akan digunakan pada tahun anggaran berikutnya (Darma, et al., 2015; Abdullah \& Mutia, 2017).

Pemerintah daerah melaksanakan fungsinya berdasarkan anggaran yang sudah ditetapkan dengan peraturan daerah, misalnya fungsi pendidikan, kesehatan, dan sosial (Afridzal, et al., 2019). Anggaran tersebut merupakan akumulasi dari kebutuhan belanja seluruh SKPD (yang memiliki besaran anggaran berbeda), yang mencerminkan beban kerja SKPD bersangkutan, baik untuk penyelenggaraan operasional maupun pelayanan publik. Pertanggungjawaban anggaran disampaikan dalam laporan realisasi anggaran (LRA), yakni laporan keuangan yang menggunakan basis kas dengan akun-akun bernama pendapatan, belanja, dan pembiayaan. LRA menyajikan informasi tentang anggaran, realisasi, dan selisih di antara keduanya. Oleh karena itu, dari LRA dapat diketahui capaian kinerja anggaran dan/atau varian anggaran, yang menunjukkan keakurasian dalam penyusunan anggaran, cerminan kualitas penganggaran pada pemerintah daerah.

Adanya senjangan dalam penyusunan anggaran, yang berimplikasi pada terjadinya varian anggaran, menunjukkan adanya masalah keagenan dalam proses penyusunan anggaran (Smith \& Bertozzi, 1998; Halim \& Abdullah, 2006; Abdullah \& Nazry, 2015; Junita, 2018) dan kekuatan politik yang terlibat di dalamnya (Weingast, et al., 1981; Abdullah, 2012;) sehingga terjadi bias dalam perumusannya (Larkey \& Smith, 1989). Birokrat juga memiliki kecenderungan moral hazard dalam penganggaran (McGuire, 1981; Blais \& Dion, 1991; Fozzard, 2001). Masalah keagenan dapat menyebabkan pengguna informasi anggaran membuat kesalahan dalam melakukan analisis dan pengambilan keputusan (Gorina, et al., 2019).

Studi terdahulu telah menemukan beberapa faktor yang dapat mempengaruhi kinerja atau serapan anggaran Pemda, namun dengan hasil beragam dan konteks berbeda. Pertama, besaran anggaran (budget size), yang mengindikasikan beban kerja dan lingkup tanggungjawab organisasi pemerintah. Hasil penelitian Puspitasari (2013) menunjukkan bahwa besaran anggaran berkaitan dengan serapan anggaran, berbeda dengan temuan 
Ruhmaini, et al. (2018) yang menyatalan bahwa besaran anggaran tidak berpengaruh terhadap serapan anggaran belanja langsung.

Kedua, perubahan anggaran. Lestari, et al. (2014) menemukan bahwa serapan anggaran berhubungan positif dengan perubahan anggaran. Zakiati (2016) menyatakan bahwa penambahan alokasi belanja pada SKPD di Kota Sabang menjadi kendala bagi SKPD dalam merealisasikan anggarannya. Lebih spesifik, temuan Ruhmaini, et al. (2018) menunjukkan bahwa perubahan anggaran berpengaruh negatif terhadap serapan anggaran belanja langsung di SKPD. Perubahan dalam komponen anggaran belanja sendiri memiliki korelasi satu sama lain, misalnya perubahan belanja tidak langsung berkorelasi positif dengan belanja langsung (Nikmawati, et al., 2016).

Ketiga, sisa anggaran tahun sebelumnya berpengaruh negatif terhadap serapan anggaran (Darma, et al., 2015). Studi terdahulu menemukan bahwa sisa anggaran tahun sebelumnya berpengaruh negatif terhadap serapan anggaran belanja langsung SKPD (Ruhmaini, et al., 2018) dan pendidikan (Afridzal, et al., 2019). Namun, secara kasuistik, beberapa SKPD di Kabupaten Gayo Lues pada tahun 2015 yang mengalami peningkatan jumlah sisa anggaran tahun sebelumnya, justru memiliki serapan anggaran yang tinggi pada tahun bersangkutan (Abdullah, 2020). Hal ini kemungkinan disebabkan adanya pemrioritasan sisa anggaran tahun sebelumnya dalam merealisasikan anggaran dan anggaran kas dilaksanakan dengan baik.

Penelitian ini menggunakan data sekunder untuk menguji pengaruh besaran anggaran belanja, perubahan anggaran belanja, dan varian anggaran tahun sebelumnya terhadap kinerja anggaran OPD (diukur dengan varian belanja tahun berjalan) pada pemerintah daerah Kabupaten Gayo Lues. Hasil penelitian ini menunjukkan bahwa perubahan anggaran dan sisa anggaran tahun sebelumnya berpengaruh negatif terhadap serapan anggaran SKPD, sedangkan besaran anggaran tidak memiliki berpengaruh. Oleh karena itu, dibutuhkan kebijakan terkait dengan upaya untuk mengurangi sisa anggaran pada akhir tahun, misalnya dengan memperketat evaluasi usulan anggaran OPD, baik dalam anggaran awal maupun anggaran perubahan. Masalah keagenan eksis karena ketidakmampuan pemerintah daerah dalam pengendalian anggaran secara komprehensif.

\section{METODE}

\section{Sampel dan Data}

Data yang digunakan dalam penelitian ini bersumber dari dokumen Anggaran Pendapatan dan Belanja Daerah (APBD) dan Laporan Realisasi APBD Kabupaten Gayo Lues untuk tahun anggaran 2016-2017. Data tersebut diperoleh dari Badan Pengelolan Keuangan Daerah (BPKD). Populasi penelitian ini adalah SKPD pada pemerintah Kabupaten Gayo Lues sebanyak 50 SKPD. Sampel dipilih menggunakan purposive sampling, dengan kriteria: tidak mengalami perubahan struktur/organisasi dan memiliki anggaran dan perubahan anggaran relatif besar, yakni lebih besar dari Rp1.000.000.000. Berdasarkan kriteria tersebut, diperoleh sampel sebanyak 44 SKPD selama tahun 2016-2017 (Lihat Tabel 1). 
Tabel 1. Sampel Penelitian

\begin{tabular}{|c|c|c|c|}
\hline No. & Nama SKPD & No. & Nama SKPD \\
\hline 1. & Dinas Pendidikan, Pemuda dan Olahraga & 23. & Satuan Polisi Pamong Praja dan WH \\
\hline 2. & Dinas Kesehatan & 24. & Sekretariat MAA \\
\hline 3. & Dinas Kelautan, Perikanan dan Pertanian & 25. & Sekretariat MPU \\
\hline 4. & Dinas Pekerjaan Umum & 26. & Sekretariat MPD \\
\hline 5. & $\begin{array}{l}\text { Dinas Perindustrian, Perdagangan, dan Koperasi } \\
\text { dan UKM }\end{array}$ & 27. & Sekretariat Baitul Mal \\
\hline 6. & Dinas Perhubungan, Komunikasi dan Informatika & 28. & Sekretariat DPRK \\
\hline 7. & Dinas Kebudayaan dan Pariwisata & 29. & Sekretariat Daerah \\
\hline 8. & Dinas Kebersihan dan Keindahan Kota & 30. & Rumah Sakit Umum Daerah \\
\hline 9. & Dinas Kependudukan dan Catatan Sipil & 31. & Sekretariat KORPRI \\
\hline 10. & Dinas Syariat Islam & 32. & Dinas Perpustakaan \\
\hline 11. & $\begin{array}{l}\text { Dinas Pengelola Keuangan dan Aset Daerah } \\
\text { (DPKAD) }\end{array}$ & 33. & $\begin{array}{l}\text { Satuan Polisi Pamong Praja dan Wilayatul } \\
\text { Hisbah }\end{array}$ \\
\hline 12. & Dinas Sosial dan Tenaga Kerja & 34. & Kecamatan Blangkejeren \\
\hline 13. & Badan Penanggulangan Bencana Daerah & 35. & Kecamatan Kutapanjang \\
\hline 14. & Badan Kesatuan Bangsa dan Politik & 36. & Kecamatan Rikit Gaib \\
\hline 15. & Badan Pemberdayaan Masyarakat Desa & 37. & Kecamatan Terangun \\
\hline 16. & Bappeda & 37. & Kecamatan Dabun Gelang \\
\hline 17. & ВКРP & 39. & Kecamatan Pining \\
\hline 18. & Kantor Perpustakaan dan Arsip & 40. & Kecamatan Pantan Cuaca \\
\hline 19. & Kantor Lingkungan Hidup & 41. & Kecamatan Tripe Jaya \\
\hline 20. & KPPTSP & 42. & Kecamatan Blangpegayon \\
\hline 21. & Kantor PP dan KB & 43. & Kecamatan Blangjerango \\
\hline 22. & Inspektorat Daerah & 44. & Kecamatan Puteri Betung \\
\hline
\end{tabular}

\section{Operasionalisasi Variabel}

Model regresi dalam penelitian ini menggunakan satu variabel terikat bernama Kinerja Anggaran (KA), dan tiga variabel bebas, yakni: Total Belanja (TB), Perubahan Belanja (PB), dan Varian Belanja Tahun Sebelumnya (VS). Definisi dan pengukuran variabel-variabel ini adalah sebagai berikut:

- Kinerja Anggaran didefinisikan sebagai sisa anggaran belanja SKPD yang tidak terserap sampai akhir tahun anggaran, yang menggambarkan kinerja anggaran SKPD selama satu tahun anggaran. Pengukuran variabel KA menggunakan selisih antara anggaran belanja setelah perubahan dengan realisasi belanja.

- $\quad$ Total Belanja (TB) adalah variabel yang menggambarkan besaran tanggungjawab suatu SKPD dalam menyelenggarakan tugas dan fungsinya. Semakin besar anggaran belanja suatu SKPD, maka semakin berat beban yang harus dilaksanakannya. Variabel ini diukur dengan menggunakan angka jumlah anggaran belanja SKPD dalam APBD murni/sebelum dilakukan perubahan selama tahun berjalan.

- Perubahan Anggaran Belanja (PB) mencerminkan penyesuaian anggaran belanja SKPD 
dengan kebutuhan dan kebijakan lain selama tahun berjalan. Besaran PB mencerminkan kualitas penganggaran SKPD yang ditetapkan pada akhir tahun anggaran sebelumnya. Variabel ini diukur dengan menggunakan angka berupa selisih antara anggaran belanja SKPD setelah perubahan dengan jumlah anggaran belanja murni/sebelum perubahan.

- Varian Belanja Tahun Sebelumnya (VS) mencerminkan kinerja anggaran belanja tahun lalu yang menambah beban SKPD selama tahun berjalan. Pengukuran variabel ini menggunakan angka selisih antara anggaran belanja setelah perubahan dengan realisasinya, keduanya menggunakan data tahun lalu.

\section{Model Analisis}

Model analisis dalam penelitian ini menggunakan regresi linear berganda menggunakan persamaaan: $Y=a+b_{1} X_{1}+b_{2} X_{2}+b_{3} X_{3}+e$, dengan $Y$ adalah Kinerja Anggaran (KA), a adalah konstanta, $b_{1-3}$ adalah koefisien regresi, $X_{1}$ adalah Total Belanja (TB), $X_{2}$ adalah perubahan anggaran belanja (PB), $X_{3}$ adalah Varian Belanja Tahun Sebelumnya (VS), dan $e$ adalah error terms atau variabel lain yang mempengaruhi variabel $Y$, yang tidak dimasukkan dalam model penelitian ini. Model ini digunakan untuk memprediksi perubahan variabel KA dengan prediktor berupa variabel TB, PB, dan VS.

\section{HASIL DAN PEMBAHASAN \\ Statistik Deskriptif}

Secara ringkas, statistik deksriptif data penelitian dapat dilihat pada Tabel 2 berikut.

Tabel 2. Analisis Statistik Deskriptif

\begin{tabular}{clccc}
\hline No. & \multicolumn{1}{c}{ Nama Variabel } & Minimum & Maksimum & Rata-Rata \\
\hline 1. & Kinerja Anggaran (KA) & -40462822 & 28.222 .310 .503 & 1.832 .069 .678 \\
2. & Total Belanja (TB) & 1.363 .500 .000 & 190.863 .347 .257 & 21.312 .714 .821 \\
& Perubahan Anggaran & -31.411 .285 .462 & 28.470 .563 .130 & 299.638 .238 \\
3. & Belanja (PB) & -21.974 .694 .381 & 26.144 .825 .935 & 98.842 .609 \\
& Varian Belanja Tahun & & \\
\hline
\end{tabular}

Sumber: Data Penelitian, 2019 (Diolah)

Variabel Kinerja Anggaran (KA) memiliki nilai rata-rata Rp1.832.069.678, dengan nilai terendah sebesar minus Rp40.462.822 dan tertinggi sebesar Rp28.222.310.503. Artinya, varian belanja SKPD, yang dihitung dengan mengurangkan anggaran belanja SKPD dengan realisasi belanja SKPD bersangkutan, relatif besar. Terlebih lagi jika dibandingkan dengan Total Anggaran Belanja (TB), yang rata-rata sebesar Rp21.312.714.821, dengan nilai terendah dan tertinggi masing-masing Rp1.363.500.000 dan Rp190.863.347.257. Jika dibandingkan antara rata-rata KA dengan rata-rata TB, diperoleh angka 0,08596 atau 8,6\%. Hal ini bermakna bahwa terjadi varian anggaran atau ketidak-akuratan dalam memprediksi anggaran sebesar 8,6\% pada SKPD Kabupaten Gayo Lues selama tahun 2016-2017. 
Variabel perubahan belanja (PB) memiliki nilai rata-rata sebesar Rp299.638.238, dengan nilai terendah sebesar minus Rp31.411.285.462 dan tertinggi sebesar Rp28.470.563.130. Nilai terendah adalah perubahan terbesar berupa penurunan, sedangkan nilai tertinggi adalah jumlah terbesar penambahan anggaran belanja. Secara rata-rata, perubahan anggaran adalah 1,41 persen dari jumlah anggaran belanja di awal tahun (murni).

Variabel varian anggaran tahun sebelumnya (VS), sebagai pengukur kinerja anggaran tahun lalu, memiliki nilai rata-rata sebesar Rp98.842.609, lebih rendah dari tahun ke- $n$ yang sebesar Rp1.832.069.678. Hal ini bermakna bahwa akurasi anggaran semakin membaik dari tahun 2016 ke tahun 2017.

\section{Hasil Pengujian Hipotesis}

Hasil pengolahan data dengan menggunakan model regresi linier berganda untuk pengujian hipotesis dapat dilihat pada Tabel berikut:

Tabel 3. Hasil Pengujian Hipotesis

\begin{tabular}{|c|c|c|c|c|}
\hline \multicolumn{5}{|c|}{$\mathrm{KA}=264680636,973+0,071 \mathrm{~TB}+0,061 \mathrm{~PB}+0,259 \mathrm{VS}+\mathrm{e}$} \\
\hline $\mathrm{t}$-value & 0,480 & 5,681 & 0,746 & 2,637 \\
\hline Sig. value & 0,632 & $0,000^{*}$ & 0,458 & $0,010^{*}$ \\
\hline F-Value/Sig. & \multicolumn{4}{|c|}{$15,112 / 0,000$} \\
\hline $\mathrm{R} / \mathrm{R}^{2} /$ Adj. $\mathrm{R}^{2}$ & \multicolumn{4}{|c|}{$0,592 / 0,351 / 0,327$} \\
\hline
\end{tabular}

Catatan: * siginifikan pada $\alpha=5 \%$.

Sumber: Hasil Pengolahan Data, 2018.

Hasil pengujian dengan menggunakan model regresi ditunjukkan pada Tabel 3. Secara bersama-sama, semua variabel bebas, yakni TB, PB, dan VS berpengaruh terhadap KA (secara statistik signifikan pada $\alpha=5 \%$ dengan nilai $\mathrm{F}$ sebesar 15,112 dan nilai sig. sebesar 0,000 ). Ketiga variabel tersebut memberikan pengaruh sebesar 35,10 persen terhadap Kinerja Anggaran untuk data SKPD Kabupaten Gayo Lues tahun 2016-2017.

Beberapa determinan Kinerja Anggaran (varian belanja) telah ditemukan sebelumnya, misalnya oleh Lestari, et al. (2014), Darma, et al. (2015), Rahmah, et al. (2017), Ruhmaini, et al. (2018), dan Abdullah, et al. (2019). Mereka menyatakan bahwa Besaran Anggaran, Perubahan Anggaran dan Sisa Anggaran Tahun Sebelumnya secara bersamasama membawa dampak terhadap Serapan Anggaran. Hal yang sama dinyatakan oleh Darma, et al. (2015), bahwa serapan anggaran (kebalikan dari varian anggaran) tidak dapat dipisahkan dari peranan perubahan anggaran dan sisa anggaran tahun sebelumnya. Variabel lain yang mungkin berpengaruh adalah politik yang menyebabkan keterlambatan dalam pengesahan anggaran (Hanif \& Suparno, 2017; Rezeki \& Hasanuddin, 2017), serta perencanaan, pelaksanaan anggaran dan koordinasi dengan instansi lain (Nugroho \& Alfarisi, 2017). 


\section{Pengaruh Total Belanja terhadap Kinerja Anggaran}

Hasil regresi menunjukkan nilai koefisien regresi variabel TB sebesar 0,071, nilai $t$ sebesar 5,681 dan nilai sig. sebesar 0,000. Artinya, secara statistik variabel TB berpengaruh signifikansi positif terhadap Kinerja Anggaran (KA). Hasil ini menunjukkan bahwa Kinerja Anggaran SKPD pada Pemda Kabupaten Gayo Lues dipengaruhi oleh besaran beban yang ditanggung oleh SKPD bersangkutan. Peningkatan atau penurunan variabel total belanja sejalan dengan peningkatan atau penurunan kinerja anggaran SKPD sebesar 0,071 satuan.

Hasil ini mendukung temuan Rahmah, et al. (2017). Ia mengungkapkan bahwa Besaran Anggaran berpengaruh terhadap Serapan Anggaran. Peningkatan Besaran Anggaran membawa dampak pada meningkatnya beban SKPD, sehingga semakin sulit untuk merealisasikan anggaran tersebut. Hal ini terjadi jika diasumsikan tidak terjadi peningkatan kapasitas SKPD dalam pelaksanaan anggaran dan proses penyusunan anggaran tidak berkualitas. Namun, hal ini berbeda dengan temuan Abdullah, et al. (2019) yang menggunakan data Kota Banda Aceh, dimana tidak ada pengaruh besaran anggaran belanja terhadap serapan anggaran belanja SKPD.

Rendahnya kualitas penyusunan anggaran kemungkinan menjadi penyebab mengapa besaran anggaran berpengaruh terhadap serapan atau kinerja anggaran. Ada beberapa hal yang menandai ini, diantaranya: (1) tidak adanya standar belanja dan/atau kegiatan yang menjadi pedoman bagi SKPD dalam penyusunan RKA-SKPD; (2) penentuan pagu anggaran untuk setiap SKPD tidak didasarkan pada kebutuhan dan kemampuan SKPD dalam merealisasikannya; dan (3) adanya "intervensi" dari politisi untuk memasukkan kegiatan dalam anggaran SKPD, meskipun tidak sejalan dengan prioritas pembangunan pada tahun bersangkutan.

Hasil penelitian ini memberikan pemahaman bahwa jumlah alokasi belanja SKPD yang besar menjadi alasan bagi SKPD untuk berkinerja buruk dalam pelaksanaan anggarannya. Praktik bahwa SKPD mengusulkan anggaran sendiri namun tidak selalu diakomodir oleh TAPD dan/atau DPRD, menjadi paradoks. Kecenderungan DPRD memotong anggaran yang diusulkan oleh SKPD justru mendorong SKPD melakukan penggelembungan atas usulan belanjanya (mark-up). Hal ini kadang menjadi boomerang, karena ternyata pemotongan anggaran oleh DPRD tidak terjadi. Semakin besar alokasi anggaran belanja untuk SKPD, maka semakin tinggi kinerja anggaran menunjukkan adanya komitmen SKPD untuk merealisasikan anggaran yang menjadi tanggungjawabnya.

\section{Pengaruh Perubahan Anggaran Belanja terhadap Kinerja Anggaran}

Nilai koefisien variabel Perubahan Anggaran Belanja (PB) bertanda positif dengan nilai sebesar 0,062 memiliki makna bahwa setiap terjadi kenaikan anggaran belanja dalam perubahan anggaran sebesar 1 kali atau 100\%, maka realisasi belanja SKPD akan meningkat sebesar 0,061 kali atau 6,1\%. Nilai sig. variabel PB sebesar 0,458 menunjukkan bahwa variabel ini tidak berpengaruh secara siginifikan terhadap varian anggaran SKPD. Artinya, varian belanja SKPD tidak terkait dengan perubahan anggaran belanja pada periode bersangkutan.

Kecenderungan penambahan alokasi belanja pada saat perubahan anggaran ternyata tidak berdampak pada penurunan varian anggaran, begitu juga sebaliknya. Meskipun sebagian penambahan alokasi belanja bersumber dari sisa anggaran riil (kenaikan dalam 
anggaran untuk sisa anggaran tahun sebelumnya setelah audit oleh auditor independen selesai), ternyata tidak tidak terkait dengan varian anggaran atau serapan anggaran. Menurut Anessi-Pessina, et al. (2012), perubahan anggaran justru digunakan untuk memperbaiki kinerja anggaran, dimana varian anggaran belanja semakin kecil.

Temuan ini menarik. Artinya, perubahan anggaran pada SKPD di Pemda Kabupaten Gayo Lues tidak sejalan dengan konsep yang menyatakan bahwa perubahan atau penyesuaian anggaran adalah untuk memperbaiki kinerja (Forrester \& Mullins, 1992; Anessi-Pessina, et al., 2012). Berdasarkan data beberapa SKPD, perubahan anggaran belanja langsung relatif tinggi, terutama berupa penurunan alokasi belanja. Namun, model regresi ternyata tidak menemukan adanya kaitan antara perubahan anggaran dengan varian anggaran, yang merupakan indikator dari kinerja anggaran (Abdullah, et al., 2019).

Varian anggaran merupakan indikasi adanya ketidak-akuratan dalam penganggaran, sekaligus sebagai dampak dari adanya senjangan anggaran (Abdullah, et al., 2019). Secara teknis, bagi sebagian besar birokrat daerah, perubahan anggaran sering dipandang sebagai perluasan dari proses anggaran (Forrester \& Mullins, 1992). Hanya saja, proses perubahan anggaran (rebudgeting) relatif tidak terbuka dan cenderung sangat teknis, sehingga memberi peran lebih besar kepada administratur, bukan pada publik dan legislatif (Anessi-Pessina, et al., 2012). Menurut Forrester \& Mullins (1992), rebudgeting memiliki dampak berbeda untuk fungsi pelayanan yang berbeda. Temuan Lestari, et al. (2014) dan Darma, et al. (2014) menunjukkan adanya pengaruh positif perubahan anggaran terhadap serapan anggaran pada pemerintah daerah, sementara temuan Ruhmaini, et al. (2018) menunjukkan hasil sebaliknya, yakni perubahan anggaran berpengaruh negatif terhadap serapan anggaran. Hasil-hasil penelitian ini berbeda dengan hasil penelitian di Kabupaten Gayo Lues, yang tidak menemukan adanya pengaruh PB terhadap KA.

\section{Pengaruh Varian Belanja Tahun Sebelumnya terhadap Kinerja Anggaran}

Hasil pengolahan data menunjukkan bahwa variabel Varian Belanja Tahun Sebelumnya (VS) memiliki nilai koefisien regresi sebesar 0,259. Artinya, setiap kenaikan variabel VS sebesar satu kali atau 100\%, maka realisasi belanja SKPK akan menurun (atau varian tahun berjalan naik) sebesar 25,90\%. Nilai signifikansi ( $p$-value) variabel VS sebesar 0,010, lebih kecil dari tingkat signifikansi 0,05, menunjukkan bahwa secara statistika, variabel VS berpengaruh positif terhadap KA pada SKPD pemerintah Kabupaten Gayo Lues.

Penurunan Kinerja Anggaran SKPD (atau varian belanja meningkat) sebagai akibat dari kenaikan VS menunjukkan bahwa "warisan" dana anggaran yang berasal dari tahun lalu akan mengurangi kemampuan SKPD dalam menyelesaikan seluruh alokasi anggaran yang menjadi kewajibannya selama tahu berjalan. Varian belanja tahun sebelumnya secara empiris terbukti akan membebani anggaran tahun berikutnya karena harus diprioritaskan pelaksanaannya di awal tahun anggaran. Kondisi ini menunjukkan bahwa kinerja anggaran tahun lalu berpengaruh positif terhadap kinerja anggaran tahun berjalan. Hasil penelitian ini relevan dengan temuan Darma, et al. (2015), Syahputra (2016), Rahmah, et al. (2017), dan Ruhmaini, et al. (2018) yang menyatakan bahwa serapan anggaran dipengaruhi oleh sisa anggaran tahun sebelumnya. 
Varian belanja tahun sebelumnya pada suatu SKPD mencerminkan ketidakmampuan SKPD merealisasikan seluruh anggaran belanja yang sudah ditetapkan untuk SKPD tersebut pada tahun lalu. Varian belanja tahun lalu memiliki kaitan logis dengan tahun berjalan. Fenomena menarik di lapangan adalah seringnya keputusan politik dalam penganggaran untuk perubahan tahun lalu yang "membebani" anggaran pada tahun berikutnya sebagai kegiatan luncuran atau lanjutan. Keputusan politik dimaksud adalah mengalokasikan sumberdaya untuk suatu kegiatan pada saat perubahan anggaran dilakukan, meskipun sampai akhir tahun anggaran bersangkutan diyakini tidak dapat diselesaikan, dengan harapan akan ada "proyek luncuran" yang akan dilaksanakan pada tahun berikutnya. Praktik ini merupakan bentuk perilaku oportunistik pengambil keputusan anggaran sebagai agent, yang membuat keputusan untuk keuntungan pribadi (self-interest) dengan mengorbankan kepentingan sebagian principal-nya, yakni masyarakat pembayar pajak. Masyarakat dirugikan karena akan ada kegiatan tahun berjalan yang tidak tercapai targetnya sebagai implikasi dari pemrioritasan "proyek luncuran" yang lahir sebagai akibat adanya sisa anggaran tahun lalu ini.

Kegiatan yang tidak dapat diselesaikan sampai akhir tahun anggaran akan dilanjutkan pelaksanaan kegiatannya pada tahun anggaran berikutnya, tanpa perlu menunggu persetujuan DPRD untuk menyetujui penetapan Perda tentang APBD tahun berikutnya. Sisa anggaran dari tahun lalu untuk penyelesaian proyek yang sudah ditetapkan dapat digunakan langsung, meskipun APBD belum ditetapkan dalam bentuk Perda dan/atau peraturan kepala daerah. Pelaksanaan kegiatan yang dananya bersumber dari sisa anggaran tahun lalu akan diprioritaskan oleh SKPD, meskipun kegiatan dan anggaran yang baru untuk tahun berjalan telah ditetapkan.

Kegiatan lanjutan yang dananya telah tersedia dengan pasti akan dilaksanakan terlebih dahulu, sementara kegiatan baru untuk tahun anggaran berkenaan harus melalui proses administrasi dan tendering sebelum dilaksanakan. Adakalanya terjadi masalah atau ada kendala dalam pelelangan dan pelaksanaan kegiatan tahun berjalan sehingga sampai akhir tahun anggaran belum terealisasi sepenuhnya, yang berakibat pada serapan anggaran yang lebih rendah (Sukadi, 2012). Ketika kegiatan lanjutan sudah "cukup" untuk memenuhi "preferensi gizi SKPD", maka pelaksanaan kegiatan murni tahun berjalan bukanlah prioritas yang menjadi kewajiban untuk diselesaikan selama tahun berjalan. Sangat mungkin kegiatan tahun berjalan sengaja tidak diselesaikan agar bisa menjadi "tabungan" untuk awal tahun berikutnya melalui media SILPA (sisa lebih pembiayaan anggaran) pada akhir tahun.

\section{Implikasi Hasil Penelitian}

Ada beberapa hal yang perlu dilakukan pemerintah daerah, yakni: pertama, perlunya memperhatikan alasan perubahan anggaran terkait dengan sisa anggaran yang dapat terjadi sebagai akibat dari perubahan tersebut. Fenomena di SKPD menunjukkan adanya ketidakmampuan dalam menyusun rencana belanja secara baik, sehingga melakukan "revisi" pada saat perubahan anggaran di tahun berjalan. Adakalanya "revisi" ini sudah direncanakan sejak awal, misalnya dengan cara menggelembungkan anggaran, terutama untuk kegiatan yang selesai dilaksanakan sebelum perubahan anggaran, untuk kemudian "digeser" ke kegiatan lain yang anggarannya dianggap kurang. 
Kedua, realisasi anggaran belanja harus direncanakan dengan baik agar tidak menumpuk pada akhir tahun anggaran. Pelaksanaan kegiatan biasanya mulai dilaksanakan di triwulan kedua karena di triwulan pertama pemerintah daerah masih disibukkan dengan urusan administrasi keuangan dan proses pengadaan barang dan jasa (tendering). Namun, ada beberapa kegiatan yang dapat dilaksanakan sejak awal, terutama yang bersifat rutin dan kegiatan yang tidak membutuhkan proses pelelangan (boleh penunjukan langsung).

Ketiga, memberikan insentif kepada SKPD yang dapat merealisasikan anggarannya secara efektif dan efisien, sehingga serapan anggaran tetap tinggi. Serapan anggaran pada suatu kegiatan yang tidak mencapai seratus persen sering terjadi karena adanya efisiensi dalam pelaksanaannya, sehingga perlu mendapat apresiasi dari pimpinan daerah. Efisiensi ini bisa menjadi dasar pertimbangan untuk menentukan standar belanja kegiatan pada periode berikutnya. Bentuk insentif yang dapat diberikan kepada SKPD atau pejabat di SKPD tersebut adalah alokasi anggaran untuk kegiatan yang bisa membuat mereka berkembang, seperti mengikuti pelatihan, workshop, atau seminar di luar daerah, yang relevan dengan fungsi dan tugas mereka. Selain alokasi anggaran, mereka juga dapat diberikan piagam penghargaan atau nominasi sebagai SKPD terbaik dengan mendapat hadiah sejumlah uang.

Keempat, melakukan analisis tentang penyebab terjadinya penumpukan realisasi anggaran pada akhir tahun anggaran dan melibatkan stakeholders dalam melakukan pengawasan atas pelaksanaan kegiatan di lapangan. Proses lelang dalam pengadaan barang dan jasa sering bertele-tele dan kolutif, sehingga tidak berjalan lancar sebagaimana mestinya. Begitu juga dengan keterlambatan dalam penyelesaian administrasi oleh staf yang tidak berkompeten, sehingga pelaksanaan kegiatan dan pembayarannya baru dapat dilakukan menjelang akhir tahun anggaran (triwulan ketiga dan keempat). Penggunaan teknologi informasi dapat mengefisienkan proses administrasi ini.

Implikasi untuk penelitian selanjutnya adalah: pertama, menggunakan pendekatan campuran (mixed methods) dalam mengungkap faktor-faktor yang mempengaruhi serapan anggaran. Artinya, kombinasi data kuantitatif perlu dilengkapi dengan data kualitatif, sehingga penjelasan tentang determinan serapan anggaran bisa lebih lengkap dan komprehensif. Aspek keperilakuan dan politik kadang sulit dijelaskan dengan data kuantitatif, padahal sangat penting dalam penganggaran dan pelaksanaan kegiatan di lapangan.

Kedua, perlunya menambah beberapa variabel bebas dan pemoderasi, mengingat praktik perubahan anggaran terkait dengan variabel lain yang tidak dimasukkan dalam penelitian ini. Sebagai contoh adalah budaya organisasi, politik anggaran, kebijakan anggaran pemerintah pusat/provinsi, pemilihan umum kepala daerah/legislatif, dan adanya krisis ekonomi.

Ketiga, membandingkan hasil penelitian yang menggunakan data pada pemerintah daerah yang menerapkan status otonomi khusus dengan yang tidak berstatus otonomi khusus. Hal ini terkait dengan ketergantungan fiskal atau kemandirian daerah sebagai akibat dari adanya dana otonomi khusus yang menjadi sumber pendanaan penting bagi pemerintah daerah yang berstatus otonomi khusus.

Terakhir, melakukan kajian lebih mendalam tentang urusan atau sektor yang memiliki dampak langsung terhadap pelayanan publik, sehingga dapat dipahami perilaku belanja 
secara lebih komprehensif. Kebijakan anggaran untuk SKPD yang melaksanakan fungsi pelayanan kesehatan (Dinas Kesehatan) berbeda dengan SKPD yang melaksanakan fungsi penyediaan infrastruktur (Dinas Pekerjaan Umum), begitu juga dengan fungsi social (Dinas Sosial) dan pertanian (Dinas Pertanian). Hal ini sejalan dengan pernyataan Forrester \& Mullins (1992) yang menyatakan bahwa rebudgeting memiliki dampak berbeda untuk fungsi pelayanan yang berbeda.

\section{SIMPULAN}

Penelitian ini menemukan bahwa total belanja dan varian belanja tahun sebelumnya berpengaruh terhadap kinerja anggaran pada SKPD di pemerintah daerah Kabupaten Gayo Lues, sedangkan perubahan belanja yang tidak berpengaruh. Persentase varian belanja SKPD adalah sebesar 8,6\% dari total belanja SKPD bersangkutan. Hasil ini memberi bukti tambahan terkait faktor-faktor yang dapat dikaitkan dengan kinerja anggaran institusi pemerintahan daerah, seperti telah diteliti sebelumnya oleh Sukadi (2012), Priatno \& Khusaini (2013), Lestari, et al. (2014), Darma, et al. (2015), Syahputra (2016), Zakiati (2016), Rahmah, et al. (2017), dan Ruhmaini, et al. (2018).

Ada beberapa keterbatasan dalam penelitian ini, di antaranya: penggunaan sampel kecil dan hanya pada satu pemerintah daerah, menggunakan data sekunder terbatas untuk dua tahun, dan menggunakan regresi linier berganda biasa, tanpa pemoderasi dan/atau pemediasi. Penelitian selanjutnya dapat menggunakan pendekatan berbeda (termasuk mixed method) dan menggali determinan lain untuk tujuan mendalami isu kinerja anggaran untuk OPD dan Pemda ini, terutama dengan menggunakan perspektif keagenan (agency theory).

\section{PUSTAKA ACUAN}

Abdullah, Syukriy. 2008. Penganggaran Partisipatif di Pemerintahan dan Bisnis: Perbedaan dan Isu-isu Penelitian. Desember 25. https://syukriy.wordpress.com/2008/12/25/penganggaranpartisipatif-di-pemerintahan-dan-bisnis-perbedaan-dan-isu-isu-penelitian/ (5/3/2020).

2012. Perilaku Oportunistik Legislatif dan Faktor-Faktor yang Mempengaruhinya: Bukti Empiris dari Penganggaran Pemerintah Daerah di Indonesia. Disertasi. Yogyakarta: Fakultas Ekonomika dan Bisnis, Universitas Gadjah Mada.

2013. Perubahan APBD. https://syukriy.wordpress.com/2013/04/22/perubahanapbd/ (Akses 2/2/2020).

2016. Varians Anggaran Pendapatan dan Varians Belanja Daerah: Sebuah Pengantar. https://syukriy.wordpress.com/2016/11/26/analisis-varian-anggaran-pemerintah-daerahpenjelasan-empiris-dari-perspektif-keagenan/ (Akses 2/2/2020).

2020. Analisis Belanja Daerah Kabupaten Gayo Lues, 2017-2018. Kertas Kerja. Banda Aceh: FEB Universitas Syiah Kuala.

\& Afrah Junita. 2016. Bukti Empiris tentang Pengaruh Budget Ratcheting terhadap Hubungan antara Pendapatan Sendiri dan Belanja Daerah pada Kabupaten/Kota di Aceh. MODUS 28 (2): 185-201.

\& Ramadhaniatun Nazry. 2015. Analisis Varian Anggaran Pemerintah Daerah: 
Penjelasan Empiris dari Perspektif Keagenan. Jurnal Samudra Ekonomi dan Bisnis 6(2): 272-283.

\& Riza Rona. 2014. Pengaruh Sisa Anggaran, Pendapatan Sendiri dan Dana Perimbangan terhadap Belanja Modal. Iqtishadia 7(1): 179-202. DOI: http://dx.doi. org/10.21043/iqtishadia.v7i1.1106

, Muhtar Muhtar, Marwan Marwan, \& Aliamin Aliamin. 2019. Serapan Anggaran pada Organisasi Perangkat Daerah: Bukti Empiris dari Kota Banda Aceh. Jurnal Akuntansi Publik 2(1): 66-83. https://jap.fdasp.org.

Mulia Saputra, Dara Fazella, Hasnawati, \& Aulia Afridzal. 2019. Determinan Kinerja Anggaran Belanja Pendidikan pada Kabupaten/Kota di Aceh. Jurnal Media Riset Akuntansi, Auditing \& Informasi 19(2): 149-166. DOI: http://dx.doi.org/10.25105/mraai.v19i2.3253

Andalia, Dian, Darwanis, \& Syukriy Abdullah. 2012. Pengaruh Varian Pendapatan dan Varian Belanja terhadap Sisa Anggaran Pemerintah Daerah di Kabupaten/Kota se-Aceh. Jurnal Akuntansi Pascasarjana Universitas Syiah Kuala 2(1): 41-52.

Anessi-Pessina, Eugenio, Mariafrancesca Sicilia, \& Ileana Steccolini. 2012. Budgeting \& Rebudgeting in Local Governments: Siamese Twins. Public Administration Review. 72(6): 875-884. https://doi.org/10.1111/j.1540-6210.2012.02590.x

Blais, André \& Stéphane Dion. 1990. Are Bureaucrats Budget Maximizers? The Niskanen Model \& Its Critics. Polity 22(4): 655-674. https://doi.org/10.2307/3234823

BPKP (Badan Pengawasan Keuangan dan Pembangunan). 2011. Misteri Penyerapan Anggaran. Paris Review 3(6): 1-56.

Darma, Romaidon, Hasan Basri, \& Syukriy Abdullah. 2015. Pengaruh Waktu Penetapan Anggaran, Sisa Anggaran Tahun Sebelumnya, dan Perubahan Anggaran terhadap Serapan Anggaran pada Pemerintah Daerah Kabuapten/Kota di Aceh. Jurnal Magister Akuntansi Pascasarjana Universitas Syiah Kuala. 4(2): 18-25. http://jurnal.unsyiah. ac.id/JAA/article/view/4463

Darmastuti, Dewi \& Dyah Setyaningrum. 2019. The Effect of Discretionary Spending on Incumbent Victories in Elections. Humanities \& Social Sciences Reviews 7(4): 685-693. https://doi.org/10.18510/hssr.2019.7488.

Forrester, John P. 1993. The Rebudgeting Process in State Government: The Case of Missouri. American Review of Public Administration 23(2): 155-178. https://doi. org/10.1177/027507409302300205

\& Daniel R. Mullins. 1992. Rebudgeting: The Serial Nature of Municipal Budgetary Processes. Public Administration Review 52(5): 467-473. https://www.jstor.org/stable/976806

Fozzard, Adrian. 2001. The Basic Budgeting Problem: Approaches to Resource Allocation in the Public Sector and Their Implications for Pro-Poor Budgeting. Center for Aid and Public Expenditure, Overseas Development Institute (ODI). Working paper 147. https://www.odi.org/publications/1395-basic-budgeting-problem-approaches-resourceallocation-public-sector-and-their-implications-pro-poor

Gorina, Evgenia, Craig Maher, \&Sungho Park. 2019. Toward a Theory of Fiscal Slack. Public Budgeting \& Finance (Summer): 1-27. https://onlinelibrary.wiley.com/doi/abs/10.1111/ pbaf. 12240 
Hanif, Imam \& Suparno Suparno. 2017. Pengaruh Waktu Penetapan Anggaran dan Fiscal Stress terhadap Serapan Anggaran Pemerintah Kabupaten/Kota di Provinsi Aceh. Jurnal Ilmiah Mahasiswa Ekonomi Akuntansi (JIMEKA) 2(4): 107-115. http://www.jim. unsyiah.ac.id/EKA/article/view/5218

Joyce, Philip G. 2001. What's So Magical about Five Percent? A Nationwide Look at Factors that Influence the Optimal Size of State Rainy Day Funds. Public Budgeting \& Finance (Summer): 62-87. DOI: 10.1111/0275-1100.00050.

Junita, Afrah. 2018. Determinan Kinerja Anggaran Pemerintah Daerah dengan Perubahan Anggaran sebagai Pemediasi dan Teknologi Informasi Sebagai Pemoderasi: Studi pada Satuan Kerja Perangkat Daerah di Aceh. Disertasi. Medan: Program Doktor Ilmu Akuntansi Fakultas Ekonomi dan Bisnis Universitas Sumatera Utara.

\& Syukriy Abdullah. 2016. Pengaruh Fiscal Stress dan Legislature Size terhadap Expenditure Change pada Kabupaten/Kota di Sumatera Utara. Jurnal Akuntansi 20(3): 477-478. https://www.neliti.com/publications/77408/pengaruh-fiscal-stress-danlegislature-size-terhadap-expenditure-change-pada-kab

Larkey, P.D. \& R.A. Smith. 1989. Bias in the Formulation of Local Government Budget Problems. Policy Sciences 22(2): 123-166. https://link.springer.com/article/10.1007/ BF00141382

Lestari, Soraya, Syukriy Abdullah, \& Hasan Basri. 2014. Pengaruh Alokasi Belanja Murni dan Alokasi Belanja Perubahan terhadap Serapan Anggaran Kabuapaten/Kota di Aceh. Jurnal Magister Akuntansi Pascasarjana Universitas Syiah Kuala 3(3): 80-89. http:// jurnal.unsyiah.ac.id/JAA/article/view/4437

Lukka, K. 1988. Budgetary Biasing in Organization: Theoretical and Empirical Evidence. Accounting Organization and Society 13(3): 281-301. https://www.sciencedirect.com/ science/article/abs/pii/0361368288900050

Mayper, Alan G., Michael Granof \& Gary Giroux. 1991. An Analysis of Municipal Budget Variances. Accounting, Auditing \& Accountability Journal 4(1): 29-50. DOI: http://dx.doi. org/10.1108/09513579110003358.

McGuire, Thomas. 1981. Budget-Maximizing Governmental Agencies: An Empirical Test. Public Choice 36: 313-322. https://link.springer.com/article/10.1007/BF00123787

Meridiana, Darwanis, \& Syukriy Abdullah. 2017. Pengaruh Sisa Anggaran Sebelumnya, Perubahan Anggaran Tahun Lalu dan Besaran Anggaran terhadap Anggaran Belanja Langsung Satuan Kerja Perangkat Kabupaten (SKPK) pada Kabupaten Aceh Besar. Jurnal Magister Akuntansi Pascasarjana Universitas Syiah Kuala 6(2): 86-96. http:// jurnal.unsyiah.ac.id/JAA/article/view/7745

Miliasih, Retno. 2012. Analisis Keterlambatan Penyerapan Anggaran Belanja Satuan Kerja Kementerian Negara/Lembaga Tahun Anggaran 2010 di Wilayah Pembayaran KPPN Pekan Baru. Tesis. Jakarta: FEUI. http://lib.ui.ac.id/ detail?id=20289958\&lokasi=lokal\#parentHorizontalTab2

Negara, Perdana Kusuma, Handajani, \& Lukman Effendy. 2018. Studi Kasus Fenomena Tingkat Serapan Anggaran pada Satuan Kerja Perangkat Daerah. Jurnal Akuntansi dan Investasi 19(1): 76-91. https://journal.umy.ac.id/index.php/ai/article/view/2658 
Nikmawati, Syukriy Abdullah, \& Heru Fahlevi. 2016. Analisis Korelasi Belanja Daerah dalam Perubahan APBK Kabupaten/Kota: Studi di Aceh. Jurnal Magister Akuntansi Pascasarjana Universitas Syiah Kuala 5(3): 39-49. http://jurnal.unsyiah.ac.id/JAA/ article/view/4524

Nugroho, Rahadi \& Salman Alfarisi. 2017. Faktor-faktor yang Mempengaruhi Melonjaknya Penyerapan Anggaran Quartal IV Instansi Pemerintah (Studi pada Badan Pendidikan dan Pelatihan Keuangan). Jurnal BPPK 10(1): 22-37. https://jurnal.bppk.kemenkeu. go.id/jurnalbppk/article/view/23

Ott, Katarina, Velibor Mačkić, \& Mihaela Bronić. 2018. Budget Transparency of Local Governments: The Political Economy of City and Municipality Budgets in Croatia. Drustvena Istrazivanja 27(4): 629-647. https://doi.org/10.5559/di.27.4.03.

Peraturan Menteri Dalam Negeri (Permendagri) Nomor 13 Tahun 2006 tentang Pedoman Pengelolaan Keuangan Daerah.

Peraturan Pemerintah (PP) Nomor 58 Tahun 2005 tentang Pengelolaan Keuangan Daerah. Priatno, Prasetyo Adi \& M. Khusaini. 2013. Analisis Faktor-Faktor yang Mempengaruhi Penyerapan Anggaran pada Satuan Kerja Lingkup Pembayaran KPPN Blitar. Jurnal Ilmiah. Malang: Fakultas Ekonomi dan Bisnis Universitas Brawijaya. https://jimfeb. ub.ac.id/index.php/jimfeb/article/view/603

Puspitasari, Ratna. 2013. Studi Penganggaran Berbasis Kinerja pada Pemerintah Provinsi Jawa Timur, Jawa Barat dan DKI Jakarta. Jejaring Administrasi Publik 5(2): 356369. http://journal.unair.ac.id/ADMP@studi-penganggaran-berbasis-kinerja-padapemerintah-provinsi-jawa-timur,-jawa-barat-dan-dki-jakarta-article-9239-media81-category-8.html

Rahmah, Rahmah, Zuraida Zuraida, \& Syukriy Abdullah. 2017. Analisis Kinerja Anggaran pada Satuan Kerja Perangkat Daerah Kabupaten Bireuen. Jurnal Perspektif Ekonomi Darussalam 3(2): 213-222. http://jurnal.unsyiah.ac.id/JPED/article/view/8232

Rezeki, Nofa Sapitri \& Hasanuddin Hasanuddin. 2017. Desentralisasi Fiskal: Studi Tentang Pemerintah Kota Pekanbaru dalam Penyerapan Anggaran Pendapatan dan Belanja Daerah (APBD) Tahun 2014. JOM FISIP 4(1): 1-17. https://jom.unri.ac.id/index.php/ JOMFSIP/article/view/13847

Robbins, Donijo. 2005. Administrative Discretion: Its Use in Budgetary Analysis. Public Administration Quarterly 29(1/2): 186-200. https://spaef.org/article/720/AdministrativeDiscretion:-Its-Use-in-Budgetary-Analysis

Rubin, Irene. 1996. Budgeting for Accountability: Municipal Budgeting for 1990s. Public Budgeting \& Finance (Summer): 112-132. https://doi.org/10.1111/1540-5850.01071.

Ruhmaini, Ruhmaini, Syukriy Abdullah, \& Darwanis. 2018. Analisis Serapan Anggaran Belanja Pemerintah Kabupaten Aceh Tengah. Jurnal Perspektif Ekonomi Darussalam 4(1): 31-43. http://jurnal.unsyiah.ac.id/JPED/article/view/10912/8575

Ruwaida, Ruwaida, Darwanis Darwanis, \& Syukriy Abdullah. 2015. Faktor-Faktor yang Mempengaruhi Realisasi Anggaran Belanja Pendidikan di Provinsi Aceh. Jurnal Administrasi Akuntansi Program Pascasarjana Unsyiah 4(4): 101-110. http://jurnal. unsyiah.ac.id/JAA/article/view/4493 
Schick, Allen. 2003. The Role of Fiscal Rules in Budgeting. OECD Journal on Budgeting 3(3): 7-34. https://www.oecd-ilibrary.org/governance/the-role-of-fiscal-rules-in-budgeting budget-v3-art14-en

Smith, Robert W. \& Mark Bertozzi. 1998. Principals and Agents: An Explanatory Model for Public Budgeting. Journal of Public Budgeting, Accounting \& Financial Management 10(3): 325-353. https://doi.org/10.1108/JPBAFM-10-03-1998-B001

Steccolini, Ileana. 2004. Is the Annual Report an Accountability Medium? An Empirical Investigation into Italian Local Governments. Financial Accountability \&Management 20(3): 327-350. https://doi.org/10.1111/j.0267-4424.2004.00389.x

Sukadi, Sukadi. 2012. Analisis Faktor-Faktor yang Mempengaruhi Penumpukan Penyerapan Anggaran Belanja pada Akhir Tahun Anggaran. Abstrak Tesis. Yogyakarta: Universtitas Gadjah Mada. Laman: http://etd.repository.ugm.ac.id/index.php?act=view\&buku_ id=55894\&mod=penelitian_detail\&sub=PenelitianDetail\&typ=html

Syahputra, Ari. 2016. Analisis Faktor-faktor yang Mempengaruhi Penyerapan Anggaran dengan Perubahan Anggaran sebagai Variabel Moderating pada Pemerintah Kabupaten/Kota di Sumatera Utara. Tesis. Medan: Program Magister Akuntansi Fakultas Ekonomi dan Bisnis Universitas Sumatera Utara. http://repositori.usu.ac.id/handle/123456789/13776

Weingast, Barry R., Kenneth A. Shepsle, \& Christopher Johnsen. 1981. The Political Economy of Benefits and Costs: A Neo-classical Approach to Distributive Politics. Journal of Political Economy 89 (August): 642-64. https://www.journals.uchicago.edu/ doi/10.1086/260997

Widanaputra, A.A. \& N.P.S.H. Mimba. 2014. The Influence of Participative Budgeting on Budgetary Slack in Composing Local Governments' Budget in Bali Province. International Conference on Accounting Studies (ICAS) 2014. Kuala Lumpur, Malaysia, 18-19 August. https://www.sciencedirect.com/science/article/pii/S1877042814059138/pdf?md5=ed 4f01101d13c829b2efdd2d385a1eed\&pid=1-s2.0-S1877042814059138-main.pdf

Williams, D. W. \& T. D. Calabrese. 2016. The Status of Budget Forecasting. Journal of Public and Nonprofit Affairs 2(2): 127-160. DOI: https://doi.org/10.20899/jpna.2.2.127-160

Yuhertiana, Indrawati, Soeparlan Pranoto, \& Hero Priono. 2015. Perilaku Disfungsional pada Siklus Penganggaran Pemerintah: Tahap Perencanaan Anggaran. Jurnal Akuntansi dan Auditing Indonesia 19(1): 25-38. DOI: https://doi.org/10.20885/jaai.vol19.iss1.art3

Yuliati, Retno, Soemarso Slamet Raharjo, \& Dodik Siswantoro. 2017. Accountability and Incumbent Re-election in Indonesian Local Government. International Research Journal of Business Studies 9(3): 157-168.

Zakiati, Mulia. 2016. Pengaruh Perencanaan Anggaran dan Politik Penganggaran terhadap Perubahan Anggaran serta Dampaknya terhadap Serapan Anggaran Belanja pada SKPK Pemerintah Kota Sabang. Tesis. Banda Aceh: Program Pascasarjana Universitas Syiah Kuala. https://etd.unsyiah.ac.id/index.php?p=show_detail\&id=22011

Zarinah, Monik, Darwanis, \& Syukriy Abdullah. 2016. Pengaruh Perencanaan Anggaran dan Kualias Sumber Daya Manusia terhadap Tingkat Penyerapan Anggaran Satuan Kerja Perangkat Daerah di Kabupaten Aceh Utara. Jurnal Magister Akuntansi Pascasarjana Universitas Syiah Kuala 5(1): 90-97. www.jurnal.unsyiah.ac.id/JAA/article/view/4502/3878 